$\sqrt{B}$

J. Bio-Sci. 25: 45-56, 2017

ISSN 1023-8654

http://www.banglajol.info/index.php/JBS/index

\title{
BARRIER AND PHYSICAL PROPERTIES OF ARROWROOT STARCH- CARRAGEENAN BASED BIOFILMS
}

\author{
Giyatmi1 ${ }^{1}$, S Melanie², D Fransiska², M Darmawan² and HE Irianto $1,2^{*}$ \\ 1Food Technology Department, Jakarta Sahid University, Jakarta, Indonesia \\ ${ }^{2}$ Research and Development Centre for Marine and Fisheries Product Processing and Biotechnology, \\ Jakarta, Indonesia
}

\begin{abstract}
The demand of environmentally friendly packaging materials to overcome the high use of plastic led to increase of research effort on the development of biodegradable plastic from sustainable packaging. In this research, carrageenan films containing of arrowroot starch in the polymer blend were obtained using polyethylene glycol as plasticizer. The objective is to study the effect of different concentrations of arrowroot starch $(20 \%, 40 \%, 60 \%, 80 \%$ of carrageenan based) on barrier property (water vapor transmission rate), mechanical properties (thickness, tensile strength and elongation at break), solubility in water and whiteness index of the obtained biofilm samples. The result shows that all of them have good transparency, with $60 \%$ of concentration gives the highest Whiteness Index. The concentration of arrowroot starch that shows the best resistance to tensile strength is $40 \%$, as well as in thickness values. Concentration of $80 \%$ shows the lowest water vapor transmission rate (WVTR) permeability with $85.12 \mathrm{~g} / \mathrm{m}^{2} .24 \mathrm{~h}$, while the lowest water solubility is obtained from $60 \%$ concentration with $60.49 \%$ solubility. The recommended level of arrowroot starch to be incorporated in the process of arrowroot starch-carrageenan-based film is $60 \%$ of carrageenan.
\end{abstract}

Key words: Arrowroot starch, carrageenan, film, packaging, polyethylene glycol

\section{Introduction}

Over the past 50 years, many packaging materials use synthetic petroleum polymers as their primary source. However, the use of -petroleum-based polymers has been a problem because it has poor biodegradable capabilities (Shojaee-Aliabadi et al. 2013). The use of renewable resources that can produce biodegradable materials to reduce waste disposal problems continues to be explored as consumer concern rise on limited natural resources and environmental issues (Tavassoli-Kafrani et al. 2016). The consumer demand has shifted to eco-friendly biodegradable materials, especially from renewable agriculture by-products, food processing industry wastes and low-cost natural resources (Alves et al. 2006).

Biopolymers are biodegradable, biocompatible, and renewable. Biopolymers can also be eaten in the case of natural biopolymers. Biopolymer packaging materials also have been functioned as gas and solute barriers and can complement other types of packaging by improving quality and extending the shelf life of foods (Rhim 2012). The formation of edible film can be applied by using different biopolymers such as polysaccharides, proteins, and their blends. Polysaccharide films are made from starch, alginate, cellulose ethers, chitosan, carrageen an, or pectin, and exhibit excellent gas barrier properties (Vieira et al. 2011). In recent years, due to their good barrier properties to oxygen, carbon dioxide, and lipids as well as their superb

*Author for correspondence: harieko_irianto@yahoo.com 
mechanical properties (tensile strength and elongation at break), carrageenan and alginate have been used frequently (Tavassoli-Kafrani et al. 2016). Kappa-carrageenan can produce a transparent film with excellent mechanical and structural properties, including a tensile strength higher than those of iota and lambda carrageenan films (Park 1996). However, carrageenan and alginate have high hydrophilic features, so they have limitations as a moisture barrier (Varela and Fiszman 2011).

Another polysaccharide that can be used for source of biodegradable films is starch. One of the natural polymers that can be cast into films is starch. Like other polysaccharide polymers, physical properties of starch films are poor (Abdou and Sorour 2014). Mechanical properties of starch films have disappointedly lagged behind petroleum-based films (Chang et al. 2012). Several compounds are being added to perform a better composite film. Improvement of starch film properties can be made by blending with synthetic polymers to produce biodegradable materials (Lawton and Fanta 1994), mixing with other natural polymers in edible packaging (Arvanitoyannis et al. 1998), oradding plasticizer. Several studies about starch-carrageenan blended films to enhance their film properties have been done ( Lafargue et al. 2007, Larotonda 2007, Alves et al. 2010, Moreira et al. 2011, Abdou and Sorour 2014,).

Blending of starch with kappa-carrageenan results in the formation of an edible coating with excellent film forming and mechanical properties (Abdou and Sorour 2014). The addition of carrageenan to starch-based systems results in various physical effects which are now well documented (Larotonda 2007). Carrageenan can be functioned as a starch solution thickener, a gel-accelerating or gel-retarding agent, a gelstrengthening or gel-weakening agent, depending on the polysaccharide type (Lai et al. 1999). However, little is known about the effect of carrageenan on the properties of film cast from carrageenan-arrowroot starch mixtures. A new resource used for making biodegradable films from biopolymers is arrowroot starch. Research about the production of arrowroot starch edible films have been done previously, as a composite with other polymers (Wafiroh et al. 2011) or as an individual source (Yulianti and Ginting 2012). In this experiment, the production of composite arrowroot starch and carrageenan-based films is being investigated.

\section{Materials and Methods}

\section{Materials}

Kappa carrageenan was obtained from Eucheuma cottonii collected in Serang, Banten Province, Indonesia. While, iota carrageenan was extracted from Eucheuma spinosum harvested from Nusa Penida, Bali Province, Indonesia. The extraction process of both carrageenan followed the procedures described by Peranginangin et al. (2011). Seaweeds were soaked and then were processed through an alkaline treatment. The extraction process was performed at $60-65^{\circ} \mathrm{C}$ for 2 hours in $8 \% \mathrm{KOH}$ solutions. The seaweed and $\mathrm{KOH}$ solution ratio in the extractor tanks was 1:6 (w/v). Alkali treated seaweed then was rinsed with tap water until it reaches $\mathrm{pH}$ neutral $(\mathrm{pH} 7.0)$. Second extraction was performed at $80-85^{\circ} \mathrm{C}$ for 2 hours in water with seaweed and water ratio 1: $20(\mathrm{w} / \mathrm{v})$ by adding $3 \%$ of celite. The extract was then filtered using filter press. The concentrated extract was precipitated with Isopropyl alcohol. The precipitate was filtered and then sun dried for couples of days. The dried carrageenan was then turned into powder using a hammer mill. Arrowroot starch was obtained from traditional market in Jakarta, Indonesia. 


\section{Blend and film formation}

Arrowroot starch was blended with carrageenan by different ratios of starch with concentration $0,20,40,60$, and $80 \%$ of carrageenan weight (w/w) and mix of kappa and iota carrageenan (1:1) with concentration of $1.5 \% \mathrm{w} / \mathrm{v}$ using glycerol as a plasticizer. The starch and mixed-carrageenan were mixed in distilled water with the total volume of $100 \mathrm{ml}$. The arrowroot starch and carrageenan mixtures were cast onto flat and leveled glass plates $(16 \times 16 \mathrm{~cm})$, then the plates were held at room temperature $36-37^{\circ} \mathrm{C}$ for 24 hours. Afterwards, the films were then peeled off from the glass plates.

\section{Water vapor transmission rate}

Water vapor transmission rate (WVTR) of arrowroot starch-carrageenan biofilms was measured gravimetrically using ASTM-E 96/E96 (ASTM 2012b).

\section{Whiteness index measurement}

Whiteness index (WI) of the films was assessed through measuring the color using Hunter Lab colorimeter (Coloflex-EZ) to determine the value of $L, a, b^{1}$ ). The test was performed in accordance with ASTM D2244 (ASTM 2011) using a D65 illuminant with an opening if $14 \mathrm{~mm}$ and a $10^{\circ}$ standard observer. The colorimeter was calibrated using a standard white plate $\left(L^{*}=93.49, a^{*}=-0.25, b^{*}=0.09\right)$. The color measurements were performed by placing the film specimens over colorimeter with at least three points of each sample selected randomly to measure the color parameter of films. The following equation was used to calculate Whiteness Index (WI):

\section{$W I=100-\sqrt{(100-L)^{2}+a^{2}+b^{2}}$}

(Eq. 1)

where $L^{*}, a^{*}$, and $b^{*}$ are the color value of the arrowroot starch-carrageenan films samples and $L, a$, and $b$ are the color parameters of the white standard tile.

\section{Mechanical properties}

Films specimens were cut into rectangular strips $1 \mathrm{~cm}$ wide and $15 \mathrm{~cm}$ long after conditioning in $50 \%$ relative humidity for more than 70 hours. Tensile strength and elongation at break of arrowroot starch-carrageenan films were determined using STROGRAPH-RI (Toyoseiki, Japan). According to ASTM standard method D882 (ASTM 2012a). The initial grip separation and cross-head speed were set to $50 \mathrm{~mm}$ and $50 \mathrm{~mm} / \mathrm{min}$, respectively. A microcomputer was used to record the stress-strain curves with a minimum of five replicates of each films tested.

Thickness of the film was determined using Mitutoyo micrometer (made in Japan) with measurement range of $0.01-20.00 \mathrm{~mm}$.

\section{Water solubility}

The films solubility was determined by a method adapted from Shojaee-Aliabadi et al. (2013). The films samples were cut into square pieces of $0.4 \mathrm{~cm}^{2}$ and accurately weighed to record the dried film mass. The films were placed into test beakers with $100 \mathrm{ml}$ distilled water. The samples were immersed and shaken under constant agitation at $180 \mathrm{rpm}$ for 6 hours at $25^{\circ} \mathrm{C}$. After that period, the remaining pieces of films were 
then filtered and dried in a hot air oven at $110^{\circ} \mathrm{C}$ until a final content weight was obtained. The percentage of solubility of the films was calculated according to the equitation WS $(\%)=\left(\left(W_{0}-W_{f}\right) / W_{0}\right) \times 100$, where $W_{0}$ is the initial weight of the films expressed as dry matter and $W_{f}$ is the final weight of the desiccated undissolved films.

\section{Results and Discussion}

\section{Seaweed characteristic}

The seaweed was characterized prior to use in the process of biofilm production. This characteristic is important to know the quality of the seaweed. The characteristic of seaweed $E$. cottonii and $E$. spinosum is shown in Table 1. It can be seen that all parameters of Indonesian National Standard for dried seaweed number SNI 2690:2015 (BSN 2015) can be met by the dried seaweed. This is indicating that the raw materials used in this process were classified as good quality.

Table 1. Seaweed characteristic for raw materials of refined carrageenan.

\begin{tabular}{lccc}
\hline Parameter & $\begin{array}{c}\text { Indonesia National Standard number } \\
\text { SNI 2690:2015* }\end{array}$ & E. cottonii & E. spinosum \\
\hline Moisture content (\%) & Max 30.0 & $24.72 \pm 1.11$ & $25.85 \pm 2.34$ \\
Clean anhydrous weed (CAW; \%) & Min 50.0 & 37.14 & 50.76 \\
Impurities (\%) & Max 3.0 & 0.84 & 0.83 \\
\hline
\end{tabular}

*source : (BSN 2015)

\section{Characteristic of kappa and lota carrageenan}

The dried seaweed was then extracted to obtain the carrageenan using method explained previously. Table 2 shows the physiochemical characteristic of the kappa-carrageenan and iota-carrageenan.

Table 2. Characteristic of Kappa-carrageenan and lota-carrageenan used in the production of biofilms.

\begin{tabular}{|c|c|c|c|c|c|}
\hline \multirow[t]{2}{*}{ No. } & \multirow[t]{2}{*}{ Parameter } & \multicolumn{2}{|c|}{ Standard } & \multirow[t]{2}{*}{$\kappa$-carrageenan } & \multirow[t]{2}{*}{ i-carrageenan } \\
\hline & & $\mathrm{FAO}^{\mathrm{a}}$ & $\mathrm{FCCb}$ & & \\
\hline 1 & Gel strength & $\operatorname{Min} 5$ & $\operatorname{Min} 5$ & $45.00 \pm 7.50$ & $47.35 \pm 5.50$ \\
\hline 2 & Viscosity (at 750; cP) & $\operatorname{Min} 5$ & - & $15.00 \pm 2.50$ & $40.00 \pm 0.00$ \\
\hline 3 & Moisture content (\%) & $\operatorname{Max} 12$ & $\operatorname{Max} 12$ & $22.16 \pm 2.29$ & $27.07 \pm 0.11$ \\
\hline 4 & Ash content (\%) & $15-40$ & $\operatorname{Max} 35$ & $34.18 \pm 1.92$ & $27.15 \pm 0.36$ \\
\hline 5 & Acid-insoluble ash content (\%) & $\operatorname{Max} 2$ & $\operatorname{Max} 1$ & $0.71 \pm 0.15$ & $0.69 \pm 0.071$ \\
\hline 6 & Sulphate content (\%) & $15-40$ & - & $10.45 \pm 0.02$ & $2.953 \pm 0.23$ \\
\hline
\end{tabular}

a(FAO 2001), b(FCC 1981). 
The kappa-carrageenan and iota-carrageenan extracted from red seaweed met the standard in most of the parameter set by FAO (2001) and FCC (1981), except for moisture content. This excess moisture may be due to the unfinished drying process. If the carrageenan will be stored for a period of time, this moisture content should be reduced by employing further drying until meet the required level of moisture content.

\section{Properties of arrowroot starch - carrageenan based biofilm}

Parameters used to determine the optimum usage level of arrowroot starch on the manufacture of the starch - carrageenan based bioplastics include barrier properties, whiteness index, water solubility and mechanical properties.

\section{Barrier properties}

Fig. 1 shows the barrier properties or water vapor transmission rate (WVTR) of the films with various concentration of arrowroot-starch added to the solution of carrageenan. WVTR is important parameter for food packaging due to that the deterioration of foods is affected by moisture transferred from the product's surroundings to the interior products. Fig. 1 shows the lowest WVTR was obtained from $80 \%$ concentration of arrowroot-starch ( $\left.85.12 \mathrm{~g} / \mathrm{m}^{2} .24 \mathrm{~h}\right)$, while the highest was obtained from $0 \%$ concentration with 99.26 $\mathrm{g} / \mathrm{m}^{2} .24 \mathrm{~h}$ of WVTR. It can be seen that WVTR reduced with the increasing of arrowroot-starch concentration. This may be due to that the arrowroot-starch molecule increases the bonds between the carrageenan and reduce the water content of the films, therefore the water vapor transfer through the films also reduce (Nouri and Nafchi 2014). This result is similar with previous study about sago starch film enriched with betel leaves extract (Nouri and Nafchi 2014) and edible cassava starch incorporated with rosemary extract (PiñerosHernandez et al. 2017). This is also consistent with previous study by Abdou and Sorour (2014), where the WVTR reduces with the increasing of starch concentration added into carrageenan.

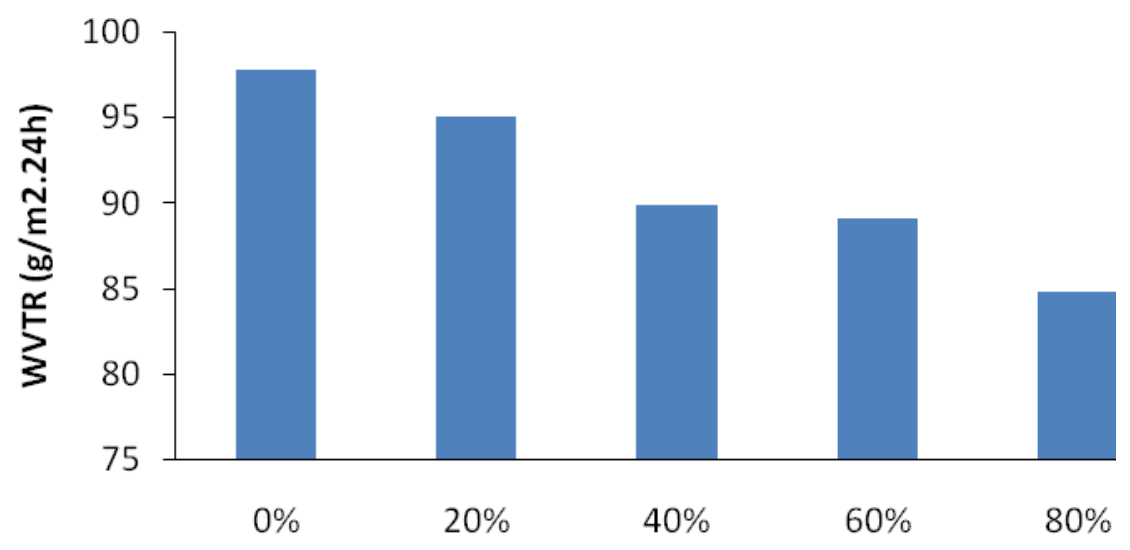

Arrowroot-starch concentration

Fig. 1. Water vapor transmission rate (WVTR) of arrowroot starch-carrageenan based films. 


\section{Whiteness index}

Fig. 2 shows the whiteness index of the films based on colorimetry measurement. The whiteness index was calculated the color parameter values of the film using Equation 1. The film with higher arrowroot-starch concentration gives higher whiteness index. The arrowroot starch content caused the film to have lower transparency meaning that higher arrowroot-starch concentration increases the opacity of the film. Development of transparent packaging materials which allow product visibility is a general trend and requirement in packaging films. Sivarooban et al. (2008) mentioned that the color of the film is an important attribute which influences its appearance, marketability and their suitability for various applications. Clear edible films are typically desirable. Based on the appearance of the films, all of the arrowroot starch concentrations produce biofilm with good transparency. This is important parameter if the films are going to use as transparent food packaging where the appearance of the food can be seen through the bioplastics.

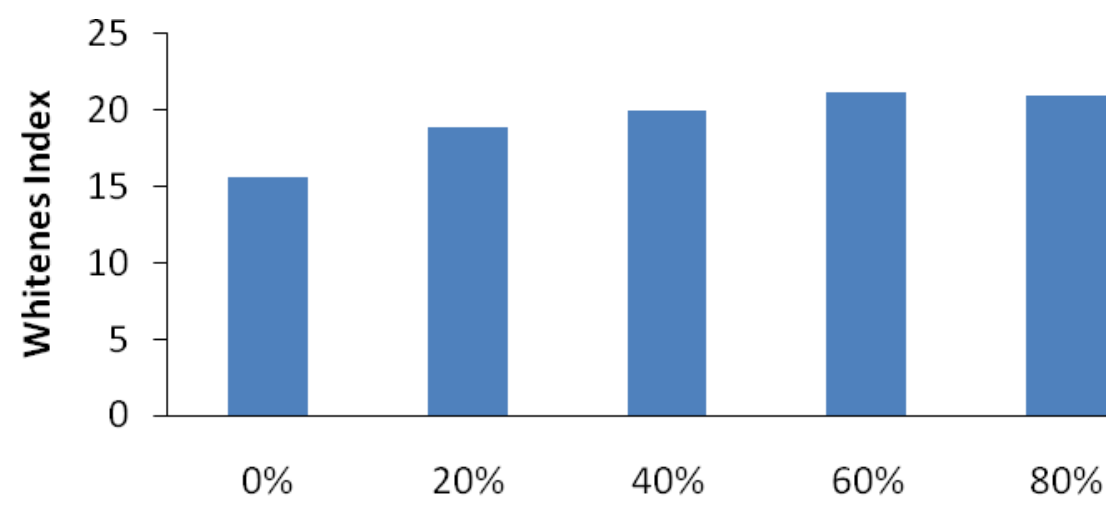

Arrowroot-starch concentration

Fig. 2. Whiteness index of arrowroot starch-carrageenan based films.

\section{Water solubility}

Fig. 3 shows the water solubility of arrowroot starch-carrageenan based films. The water solubility of the film reduced with the increasing of arrowroot starch concentration, with the lowest obtained from $60 \%$ concentration of arrowroot starch (60.49\% solubility). However, there was a discrepancy on the value of water solubility on $80 \%$ concentration of arrowroot starch, which starts to rise if compared to $60 \%$ concentration. It is possibly that there was a maximum concentration of arrowroot starch in the solution which also serves as filler to carrageenan. At $80 \%$ concentration the filler become too dense and caused the bonds of carrageenan become weaker. Film solubility in water is an essential property in selecting suitable food packaging plastics. For most food applications, films with good water insolubility are required to provide water resistance and boost shelf-life of food products. However, some food products require packaging films designed to be water-soluble before consumption of the product (Perez-Gago and Krochta 2001). Soluble 
film packaging is convenient to use in ready-to-eat products, as they melt in boiling water or in the consumer's mouth (Jirukkakul 2016).

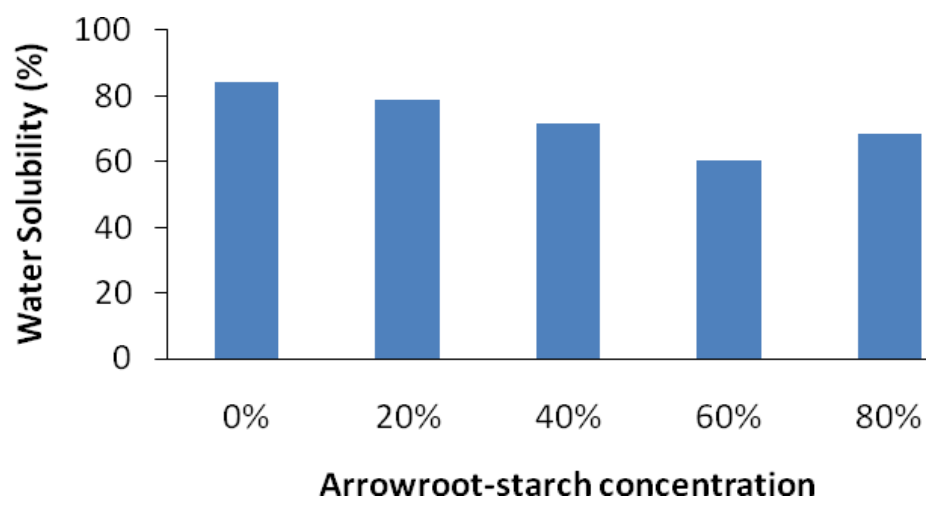

Fig. 3. Water solubility of arrowroot starch-carrageenan based films.

\section{Mechanical properties}

Mechanical properties consist of thickness, tensile strength, and elongation at break. The film produced has a plastic-like character due to the characteristics of both arrowroot starch and carrageenan themselves and also by the addition of poly ethylene glycol as a plasticizer.

\section{Thickness}

The average thickness of the arrowroot starch-carrageenan based films is shown in Fig. 4. Concentration of arrowroot starch $40 \%$ gives the thickest film $(0.644 \mathrm{~mm})$, while $0 \%$ of concentration gives the thinnest film $(0.240 \mathrm{~mm})$. From none to concentration of $40 \%$ arrowroot starch shows increasing trends, but after $60 \%$ the thickness was reduced. This is possibly because the bonds between carrageenan molecules become weaker for the concentration of arrowroot starch at $60 \%$ and above. This value was similar to the reported by Liu and Han (2005) developed pea starch films by extrusion and found thickness values (0.329 to $0.422 \mathrm{~mm}$ ). Laohakunjit and Noomhorm (2004), developed films of rice starch and glycerol and found thinner values ranging from 0.100 to $0.109 \mathrm{~mm}$ being similar to the result informed by Spada et al. (2014) made pinhão starch film with thickness values of $0.11 \pm 0.03 \mathrm{~mm}$. Maran et al. (2013) produced very thin film with thickness values ranging from 0.029 to $0.045 \mathrm{~mm}$ from film forming solution of starch, glycerol and agar. These differences were suspected probably due to by the different technique and formulation employed to process biofilms. 


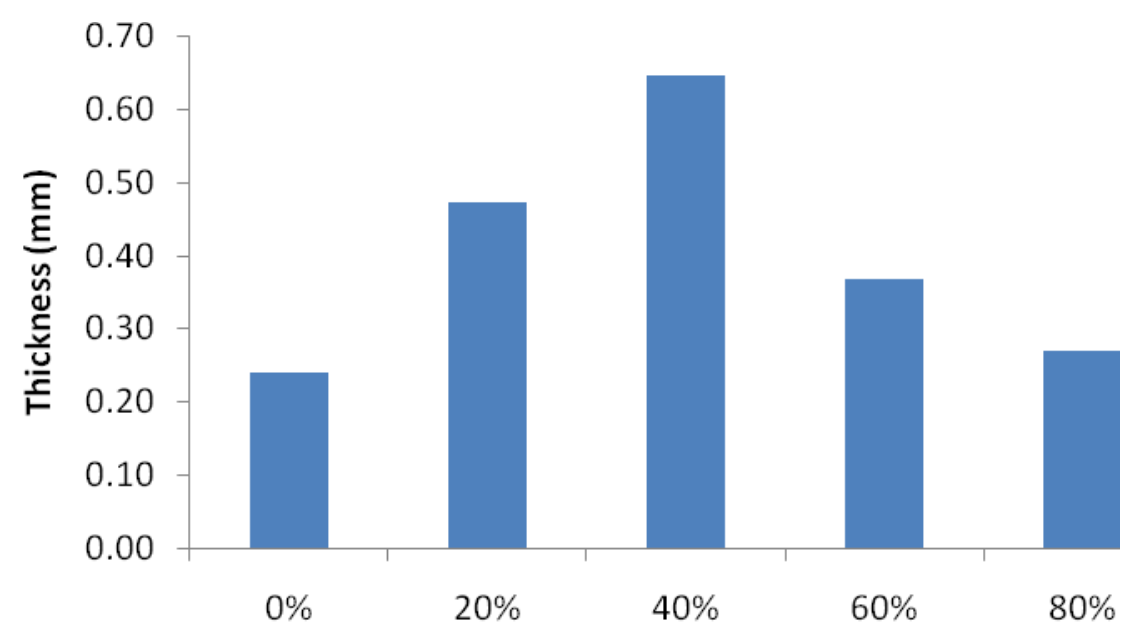

Arrowroot-starch concentration

Fig. 4. Thickness of arrowroot starch-carrageenan based films.

\section{Tensile strength}

The same trend is also observed from the tensile strength of the films as illustrated in Fig. 5. Arrowroot-starch with $40 \%$ concentration gives the best tensile strength ( $8.292 \mathrm{MPa})$. This is possibly caused by the excess starch which could loosen the bonds between carrageenan, being consistent with the previous study done by Nazurah and Hanani (2017). Plant oils incorporation to the kappa-carrageenan could make the bonds between polymers become weaker by replacing the bonds with polymer-oil interaction. Ideally the tensile strength should be constant as the film thickness varies, since the material structure is considered homogeneous regardless of the amount of suspension used to form the film. However, on the contrary, the observations showed an important dependence of tensile strength on film thickness. This phenomenon can be explained in terms of the polymer matrix formation during the drying step of the suspension. In the first step, as the water evaporated, a gel structure was formed, and due to further evaporation of water, the first film formed at the interface shrank (Bertuzzi et al. 2012). The high tensile strength values were directly related to the increase in the degree of crystallinity of the polymer matrix (Flores et al. 2007). 


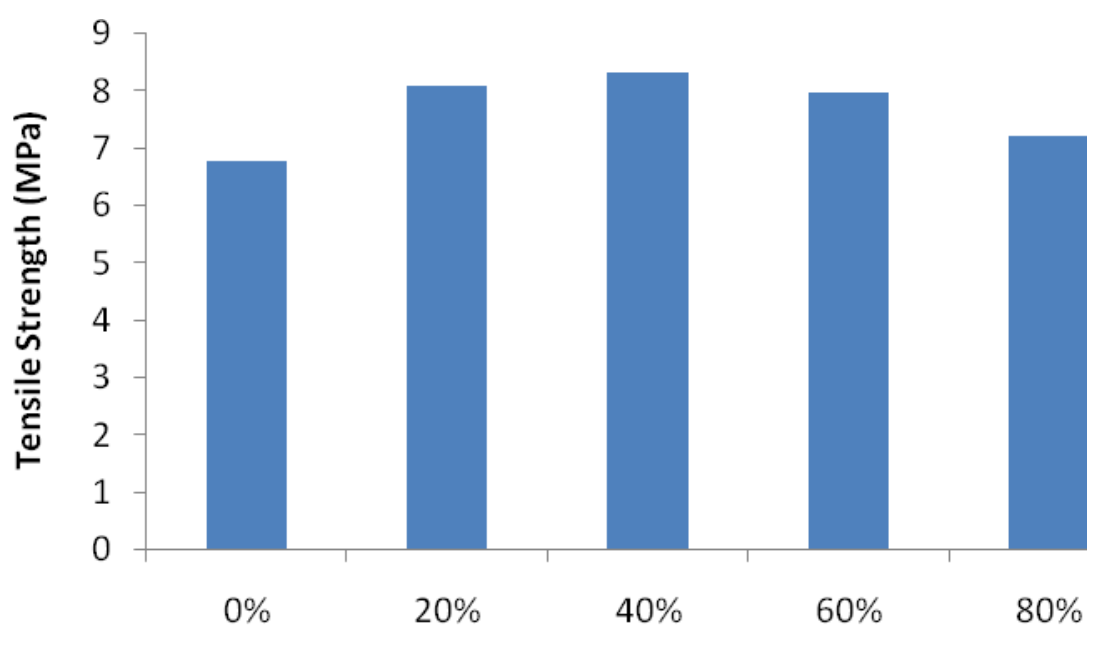

Arrowroot-starch concentration

Fig. 5. Tensile Strength of arrowroot starch-carrageenan based films.

\section{Elongation at break}

The opposite trend shows on the elongation at break of the films incorporated with arrowroot starch as presented in Fig. 6. A more stretchable matrix was formed in thicker films, probably because these films had a better organization of the starch chains and a greater cross sectional area, permitting greater extension under stress than the thinner films. Jansson and Thuvander (2004) reported the similar occurrences in starch films and Longares et al. (2004) in glycerol-plasticised whey protein isolate films. The best elongation at break is obtained from $20 \%$ of concentration, while the lowest elongation occurs from $40 \%$ concentration. 


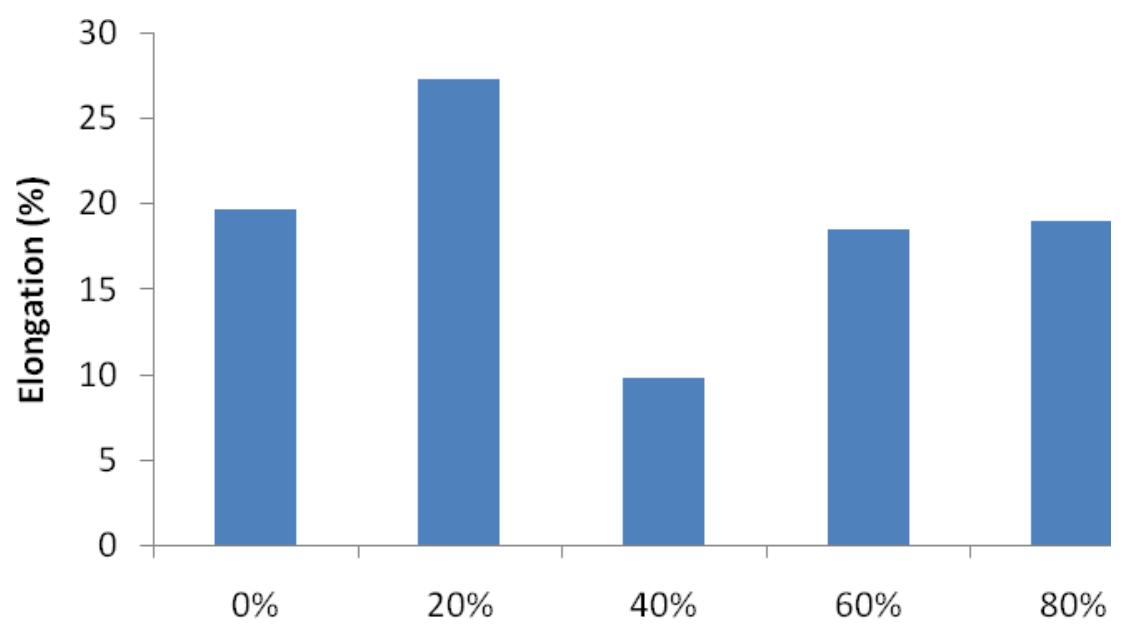

Arrowroot-starch concentration

Fig. 6. Elongation at break of arrowroot starch-carrageenan based films.

\section{Conclusion}

The results demonstrate that all experimental samples showed transparency; with arrowroot starch concentration $60 \%$ of carrageenan gives the highest whiteness index. Concentration of $80 \%$ shows the lowest water vapor permeability with $85.12 \mathrm{~g} / \mathrm{m}^{2}$. 24h of WVTR, while the lowest water solubility is obtained from $60 \%$ concentration level with $60.49 \%$ solubility. The concentration of arrowroot starch that shows the best resistance to tensile strength is $40 \%$, as well as in thickness values. The addition of arrowroot starch to carrageenan can improve the properties of the films up to $60 \%$, but above that concentration the quality of the films is decreasing. With the variation of the results between $40 \%$ up to $80 \%$ concentration, a future study with short range of arrowtroot-starch concentration need to be done to find a specific value for the manufacturing of biofilm.

\section{Acknowledgement}

The authors wish to thank the Ministry of Research, Technology and Higher Education for funding support through the National Innovation System Research Incentive (INSINAS) Program - Fiscal Year 2017 with contract number of 29/INS-2/PPK/E/E4/2017.

\section{References}

Abdou ES and Sorour MA (2014). Preparation and characterization of starch/carrageenan edible films. International Food Research Journal 21(1): 189-193.

Alves V, Costa N, Hilliou L and Larotonda F (2006). Design of biodegradable composite films for food packaging. Desalination 199: 331-333.

Alves VD, Costa N and Coelhoso IM (2010). Barrier properties of biodegradable composite films based on kappacarrageenan/pectin blends and mica flakes. Carbohydrate Polymers 79: 269-276. 
Arvanitoyannis I, Nakayama A and Aiba S (1998). Edible films made from hydroxypropyl starch and gelatin and plasticized by polyols and water. Carbohydrate Polymers 36(2): 105-119.

ASTM (2011). ASTM D2244. Standard Practice for CAlculation of Color Tolerances and Color Differences from Instrumentally Measured Color Coordinates. West Conshohocken, PA: ASTM International.

ASTM (2012a). ASTM Standard D882. Standard test method for tensile properties of thin plastic sheeting. West Conshohocken, PA: ASTM International.

ASTM (2012b). ASTM Standard E96/E96M. Standard test methods for water vapor transmission of materials. West Conshohocken, PA: ASTM International.

Bertuzzi MA, Gottifredi JC and Armada M (2012). Mechanical properties of a high amylose content corn starch based film, gelatinized at low temperature propriedades mecânicas de filme a base de amido de milho de alto teor de amilose gelatinizado em baixa temperatura. Campinas 15(3): 219-227.

BSN (2015). SNI 2690:2015 Rumput laut kering. In Standar Nasional Indonesia. Badan Standar Nasional.

Chang PR, Wu D, Anderson DP and Ma X (2012). Nanocomposites based on plasticized starch and rectorite clay: Structure and properties. Carbohydrate Polymers 89: 687-693.

FAO (2001). Carrageenan (Vol. 9), Food and Agriculture Organization.

FCC (1981). Carrageenan. (FC Codex, Ed.). Washington: National Academy Press.

Flores S, Famá L, Rojas AM, Goyanes S and Gerschenson L (2007). Physical properties of tapioca-starch edible films: Influence of filmmaking and potassium sorbate. Food Research International 40(2): 257-265.

Jansson A, and Thuvander $F$ (2004). Influence of thickness on the mechanical properties for starch films. Carbohydrate Polymers 56(4): 499-503.

Jirukkakul N (2016). The study of edible film production from unriped banana flour and riped banana puree. International Food Research Journal 23(1): 95-101.

Lafargue D, Lourdin D and Doublier J (2007). Film-forming properties of a modified starch / j -carrageenan mixture in relation to its rheological behaviour, Carbohydrate Polymers 70: 101-111.

Lai VMF, Huang AL and Lii CY (1999). Rheological properties and phase transition of red algal polysaccharide-starch composites. Food Hydrocolloids 13(5): 409-418.

Laohakunjit $\mathrm{N}$ and Noomhorm A (2004). Effect of plasticizers on mechanical and barrier properties of rice starch film. Starch/Staerke 56(8): 348-356.

Larotonda FDS (2007). Biodegradable films and coatings obtained from carrageenan from Mastocarpus stellatus and starch from Quercus suber.

Lawton JW and Fanta GF (1994). Glycerol-plasticized films prepared from starch-poly(vinyl alcohol) mixtures: effect of poly(ethylene-co-acrylic acid). Carbohydrate Polymers 23(4): 275-280.

Liu Z and Han JH (2005). Film-forming Characteristics of Starches. Journal of Food Science 70(1): 31-36.

Longares A, Monahan FJ, O'Riordan ED and O'Sullivan M (2004). Physical properties and sensory evaluation of WPI films of varying thickness. LWT-Food Science and Technology 37(5): 545-550.

Maran JP, Sivakumar V, Sridhar R and Thirugnanasambandham K (2013). Development of model for barrier and optical properties of tapioca starch based edible films. Carbohydrate Polymers 92(2):1335-1347.

Moreira R, Chenlo F, Torres MD, Silva C, Prieto DM, Sousa AMM and Gonçalves MP (2011). Drying Kinetics of Biofilms Obtained from Chestnut Starch and Carrageenan with and without Glycerol. Drying Technology 37-41. 
Nouri L and Nafchi AM (2014). Antibacterial, mechanical, and barrier properties of sago starch film incorporated with betel leaves extract. International Journal of Biological Macromolecules 66: 254-259.

Nur FNR and Hanani ZAN (2016). Physicochemical characterization of kappa-carrageenan (Euchema cottoni) based films incorporated with various plant oils. Carbohydrate Polymers vol. 157, 10.1016/j.carbpol.2016.11.026.

Park HJ (1996). Gas and mechanical barrier properties of carrageenan-based biopolymer films. Food Science and Industry 29: 47-53.

Peranginangin R, Sinurat E and Darmawan M (2011). Memproduksi Karaginan dari Rumput Laut. Penebar Swadaya Grup.

Perez-Gago MB and Krochta JM (2001). Denaturation Time and Temperature Effects on Solubility, Tensile Properties, and Oxygen. Journal of Food Science 66(5): 705-10.

Piñeros-Hernandez D, Medina-jaramillo C, López-Córdoba A and Goyanes S (2017). Edible cassava starch films carrying rosemary antioxidant extracts for potential use as active food packaging. Food Hydrocolloids 63: 488495.

Rhim JW (2012). k-Carrageenan Blend Film and Derived Clay Nanocomposite Film. Journal of Food Science 77(12): 6673.

Shojaee-Aliabadi S, Hosseini H and Amin M (2013). Characterization of antioxidant-antimicrobial K-carrageenan films containing Satureja hortensis essential oil. International Journal of Biological Macromolecules 52: 116-124.

Sivarooban T, Hettiarachchy NS and Johnson MG (2008). Physical and antimicrobial properties of grape seed extract, nisin, and EDTA incorporated soy protein edible films. Food Research International 41(8): 781-785.

Spada JC, Da Silva EM and Tessaro IC (2014). Production and characterization of pinhão starch biofilms. Revista Brasileirade Ciencias Agrarias 9(3): 365-369.

Tavassoli-Kafrani E, Shekarchizadeh H and Masoudpour-Behabadi M (2016). Development of edible films and coatings from alginates and carrageenans. Carbohydrate Polymers 37: 360-374.

Varela P and Fiszman SM (2011). Hydrocolloids in fried foods. A review. Food Hydrocolloids 25(8): 1801-1812.

VieiraMGA, Da Silva MA, Dos Santos LO and Beppu MM (2011). Natural-based plasticizers and biopolymer films: A review. European Polymer Journal 47: 254-263.

Wafiroh S, Adiarto T and Agustin ET (2011). Pembuatan dan karakterisasi edible film dari komposit kitosan-pati garut (Maranta arundinaceae L) dengan Pemlastis Asam Laurat. Media Matematika Dan IImu Pengetahuan Alam 1(4): 2011.

Yulianti R and Ginting E. (2012). Perbedaan Karakteristik Fisik Edible Film dari Umbi-umbian yang Dibuat dengan Penambahan Plasticizer. Penelitian Pertanian Tanaman Pangan 31(2): 131-136. 